\title{
MORAL QUESTIONS, LEGAL ANSWERS AND BIOTECHNOLOGICAL ADVANCES
}

\author{
Glenys Godlovitch*
}

\begin{abstract}
Moral failing is usually construed as a personal flaw, but there is another construction: where morals fail people, where our moral precepts are silent. The author of this article argues that this happens nowadays where technological advances, such as genetic engineering in medicine, raise moral questions but get legal answers. By responding to the legal issues involved, the moral questions are pre-empted. This results in answers drawn from legal categories, often with commercial perspectives, but misses the larger moral domain.
\end{abstract}

\section{AN EXAMPLE OF A KIND OF PROBLEM - KINDS OF QUESTIONS}

Suppose Jenny Gee wants a child of her own, without sex or artificial insemination and so decides to clone herself and become her own best friend. Assuming all goes according to plan, we get a Jenny-clone, physically independent, socially differentiated but as if a monozygotic twin, of an entirely different age.

I do not propose to pursue philosophical questions about personal identity. Such questions are spurious without a normative framework about the accountability and responsibility of people as interacting agents. I give the example to illustrate the extent to which our moral beliefs are limited when it comes to new situations which do not fit into our familiar patterns. The following questions indicate the kinds of topic I will focus on: Do Jenny's parents have moral obligations to Jenny-clone; in particular, do they have the same responsibilities to Jenny-clone as they did to Jenny, given that in the genetic sense Jennyclone is as much their daughter as is Jenny herself? What about the more legal issues: Could Jenny's father be expected to pay child support? Who gets named on the birth certificate as the parents? Then again, what about Jenny's geneticist physicians, what standards of professional ethics ought to be applied to them? Can they just say that she was fully aware of the medical and genetic aspects involved, and they had her informed consent, or should

\footnotetext{
* Lecturer in Law, Lincoln University, New Zealand
} 
they obtain Jenny's parents' consent too? Is there some further ethical model which human cloning shares with, say, novel treatment and new techniques?

I doubt many of us have answers to these questions, but that does not mean that the questions are frivolous, nor that answers are unnecessary. We may still be a considerable way from cloning ourselves, but it has already been done with at least one sheep.

The issue for my paper is whether ethics is limited in ways which result in there being moral questions which lack moral answers. My thesis is that not only is morality incomplete, but that it is necessarily so. And, as a practical implication of this moral failing, the questions are instead being approached and answered piecemeal within other social institutions, typically from legal perspectives, and from economic and political perspectives. While these other institutions do and must have important roles, their answers will reflect the particular norms and principles of such institutions. This is not to say that these social institutions are devoid of moral reflection, only that such reflection is not paramount and so moral aspects may give way to the need for a decision to be rendered in adversarial litigation, or for economic policy to be framed for national spending.

There is an asymmetry between the roles of the court and the roles of ethicists when confronted with the propriety of human action. Particular, identifiable individuals seek a ruling from the courts when there is a specific dispute or when the legality of a course of action is uncertain. The judge must be pragmatic, and must render a decision which is consistent with existing law and also resolves the issue between the parties. In particular, the job falling to the courts is to decide on issues arising in the technologically new areas. Yet, it is apparent that there is a reticence among judges to render judgment on what they clearly identify as raising moral concerns, such as determining who can do what with genetic material and information, or with frozen embryos. It is not open to a judge either to assert that the issue is too fraught, or that all parties are in error in their submissions, unless he also imposes his own determination on the parties. But such pragmatism is not required of the ethicist; the ethicist may serve best by challenging assumptions and producing hypothetical counter-examples without the urgent need to reach any conclusion, and certainly not a conclusion for the particular individuals in their particular circumstances.

\section{COMPLETENESS, THE RULE OF LAW AND MORAL MATHEMATICS}

\section{A Completeness and the Rule of Law}

Two classical theories of ethics have been of enormous influence. They are: firstly, the Kantian school, which looks to rational determination of universal moral duties; and, 
secondly, the consequentialist utilitarian approach, which looks to causal chains and their instrumental effects relative to some ultimate, intrinsically valuable end. ${ }^{1}$

In identifying oneself as a Kantian or utilitarian, one relies on the preferred theory to provide the moral answer to any moral problem. In this way one is presuming universality, stability and permanence. One is providing an account of how one will make future decisions, not merely reporting on how one has made decisions in the past. As with declaring oneself a Leeds United supporter, one is doing a lot more than describe an aspect of one's life up to now - one is indicating a strong likelihood of a continued interest in and favouring of the team, on the basis of which others are able to predict one's future conduct. The support is a rationale for one's conduct; so too the adherence to the particular ethical theory is both rationale and relevant evidence for predicting future decisions and actions. It is as if the domain of morals and the right answers are already there, somewhere, just waiting to be called into service.

Ordinarily we have very few ethical problems - we usually do know what to do and why - but when struck by a problem, we want the theory we espouse to indicate a resolution. We want it to be normative and prescriptive, not only descriptive. From either point of view - deontological and consequentialist - it would be a significant defect if there were things that we identify as moral issues, but where there is no moral answer. As

1 I will not be describing these two theories in any great detail. Kant's approach is basically the Universality view, set out in I Kant, Grundlegung zur Metaphysik der Sitten, translated as Fundamental Principles of the Metaphysic of Ethics (Abbott translation) 10th ed (London, Longmans, Green \& Co Ltd., 1965). There Kant maintains that one ought "Act only on that maxim [= personal reason] which you could at the same time will should become a universal law". He focuses on the rationality of moral action, to the exclusion of the effects wrought by one's action. He states that "Moral laws ... in contradistinction to natural laws, are only valid as laws insofar as they can be rationally established a priori and comprehended as necessary. In fact, conceptions and judgments regarding ... conduct have no moral significance, if they contain only what may be learned from experience...; one is ... misled into making a moral principle out of anything derived from this latter source." He is famous for taking the high moral road, for the principles that one must always treat others as "ends in themselves and never as a means [to an end]" and for autonomy. Modern day Rights theories trace back to Kant, with rights as the corollary of duties in a Hohfeldian schematic. By contrast, the utilitarians are teleological in outlook, looking to cause and effect chains, with a view to the attainment of some intrinsic value, rather than rationallyfocused. They set some overall goal or goals as having intrinsic value - often the Greatest Happiness of the Greatest Number - then gauge moral worth of an action instrumentally. They engage in arithmetic like accountants toting up columns and seek to calculate whether there is an overall surplus of good over bad outcomes, relative to the ultimate goal. This approach is the counterpart to cost/benefit analysis in economics. The most famous proponents of utilitarianism are Bentham and Mill, both of whom, along with John Austin, had a strong influence in the development of modern positivist jurisprudence and the decline of Natural Law in the common law jurisdictions in the 19 th century. 
indicated, ${ }^{2}$ Kant construes morals in terms of rationally necessary moral duties. These are principles under the single Categorical Imperative: Act only on that maxim whereby thou canst at the same time will that it should become a universal law. ${ }^{3}$ The litmus test for an action is whether one's reason applies equally to all rational, moral agents. This is referred to as the universalisability requirement. But in Kant himself and in his commentators very little attention is paid to whether the litmus test for moral behaviour - universalisability - rests on universal law in a sense that goes more like this: For every morally challenging situation, there is some moral law. Similarly, consequentialists need their theory to generate prescriptions. So they too must go beyond the accountant analogy where the tallying is done on previously created records, and must establish matrices axiomatically, to generate future prescriptions, where there are no current records. This requires that the matrix for the arithmetic precede the problem. So then, let me consider whether ethics is or ever can be considered as complete - that is, whether for absolutely any and every question, there exists some appropriate moral answer.

The arguments in favour of the completeness of ethics are along the lines that any particular moral theory does in fact have answers to most moral questions, and in theory provides a decision procedure or rubric for dealing with any new situation, basically by saying, "And so on", where the inquirer is instructed to continue to apply the method prescribed in the theory. Moral theories are thought of as practical reasoning, with algorithms fit to provide answers for any circumstances. So you either try to generate a rationally necessary moral universal law, or do more calculations about the likely consequences of whatever, as the case may be and, if you go on long enough, the answer will come out QED.

In many ways the classical views of morals are the counterpart to the doctrine of precedents and stare decisis in the rule of law. This is the doctrine in common law that once a case has been finally decided that decision must not be disturbed, and once established it constitutes a precedent authority for subsequent cases in lower courts, such that they must conform with the precedent, or demonstrate a difference which is significant enough to warrant a departure. The supposed justification for the doctrine of precedents is threefold: first, it establishes certainty - it provides fair warning - giving people a way of knowing what is legally required of them; second, like cases are treated alike; and, third, there is a finality in any given case. But notice that even when a precedent is not followed it still

2 Aboven 1.

3 Kant, Above n 1, 46. 
remains (albeit with a narrowed scope of application), to be determinative of subsequent cases that are like it in the relevant respects, whatever they may be - finding the difference means that the earlier case is not a precedent for the current matter. The new decision is an addition to the body of law; the whole body is consistent, at least in principle.

So, once determined, precedents acquire a hallowed status, the law on the point has been fixed. Some argue that it has always been fixed, that the courts merely discover or disclose the true nature of law. These kinds of view are the so-called "Natural Law" theories which generally hold that law exists independent of any particular decision. ${ }^{4}$ Natural Law supporters tend to hold that law and morals are inseparable. Modern Rights theories tend to be versions of Natural Law theories. For instance, in Stephen Guest's exposition of his philosophy of law Ronald Dworkin is said to identify himself within the Natural Law tradition. ${ }^{5}$ Such views construe rights as the corollaries of duties, and thus are Kantian in style.

Other people argue that although it is important to have the features of fixity, notice and equality, the law is not discovered or disclosed like so much natural science, but is "determined" or posited, by people - especially, judges - who establish the precedents. Judges, it is held, are not like a palaeontologist discovering a previously unknown dinosaur, but a bit like the priest declaring the couple to be man and wife, ${ }^{6}$ although judges must also interpret the history of their own institution - the precedents - along with the governing legislation, apply them to the facts as found and then issue a judicial decision. ${ }^{7}$ The lawmakers adopt a formal stance and concomitant roles in the appropriate forum with the appropriate trappings and enact legislation which, if constitutional niceties are duly met, subsequently becomes the law of the land. Historically this kind of approach in legal

4 Natural law theories prevailed in English common law until well into the 19th century. A major exponent of the school in English jurisprudence was of course Blackstone, against whose writings Bentham was to fulminate so successfully. It is associated also with classical approaches to international law following Grotius, along the lines of the Roman law of jus gentium. It is easy to see how law could be thought of as natural given the views about the status of the sovereign, as having Divine right, or of the Pope as the pontiff - literally the bridgehead [to heaven]- any prescribed law will trace back ultimately to God.

5 S Guest Ronald Dworkin (Stanford, California, Stanford University Press, 1991) 7.

6 The performative nature of the official action, circumscribed by all kinds of social conventions and role requirements is key here. J L Austin's discussions of performatives is still relevant to this approach. See his How To Do Things With Words (Oxford, Clarendon Press, 1962).

7 Judgment-making as an exercise in discovery and interpretation is the subject matter of a very recent publication. See Bruce Anderson "Discovery" in Legal Decision-Making (Dordrecht, Kluwer Academic Publishers, 1996). 
thinking is identified with the Legal Positivists, most of whom owe their allegiance to Bentham and to the utilitarian school of ethics, and most of them were supporters of codifying the law. They separate law from morals, in the sense that they hold it is one thing to inquire whether a certain proposition is a statement of law, and an entirely different thing to ask whether it is good law. ${ }^{8}$ The consequence of the positivist approach is that law is seen as made up, not discovered, although the rules and procedures for valid rule-making must pre-exist the exercise. ${ }^{9}$

\section{B Moral Marksmen and Mathematicians}

Whereas in law it is at least an ongoing issue whether or the extent to which law is discovered as distinct from "made-up as we go", there is a sense of repugnance at the thought that we should be inventing ethics. For the Kantian it is as though there were a great preexisting universe of moral certainties just waiting to be identified and revealed. All we need to do is find the appropriate trajectory and we will be able to discover the right, the true answer. The appropriate trajectory, of course, will be the one that sends back the right answer, and for Kant that is the universalisability test. This will provide the moral counterpart to natural laws - it will disclose or reveal what was there all along. The moral marksman simply has to see whether her maxim falls in the circle of universal moral prescript, and if it does then she has scored a moral bull's eye. If her maxim fails the universality test, then hers is not a moral law at all and she must try again, if she is to act morally. ${ }^{10}$ But, the problem seems to be that the Kantian moral marksman has to perform blindfolded. She has no prior knowledge of the whereabouts of the target, only the method for determining successful shooting. But if the Kantian is like a blindfolded marksman, the

8 Unlike the Natural Law theorists, Legal Positivists acknowledge an immoral, objectionable item as law provided it meets the rules for valid law-making in that society. This is an implication of the separation of law and morals. This topic is addressed in famous debates involving $\mathrm{H} \mathrm{L} \mathrm{A.} \mathrm{Hart} \mathrm{in}$ the 1950s; see H L A Hart Positivism and the Separation of Law and Morals (1958) 71 Harvard Law Review 592 and L Fuller Positivism and Fidelity to Law - A Reply to Professor Hart, (1958) 71 Harvard Law Review 630. I think one needs to bear in mind how relatively recent were the horrors of Germany's ethnic purification and genocidal policies and actions during the War, and the defences of "only following orders" at the Nuremberg trials to get a full sense of the importance of the issue of the connection between law and morals.

9 The distinction here is between primary rules and secondary rules in H L A Hart's sense. See H L A Hart The Concept of Law (Oxford, Oxford University Press, 1961).

10 Elsewhere in the Grundlegung (above n 1) and in the Critique of Practical Reasoning (New York, Garland Pub, 1976) Kant discusses at length the difference between prudential reasoning, which is purposive, (the hypothetical practical imperative), and categorical reasoning, the categorical imperative. He will have no truck with the view that casts prudence as a form of moral reasoning, if only because it is inextricably bound up with purposes and ends. Prudence may be a good practice to adopt for certain purposes, but it has no independent value in Kant's eyes and so lacks the impartiality he demands. 
consequentialist is like the accountant with an indefinite number of rows and columns to tally and no way of knowing when he has reached the end of his sums. For the consequentialist, the answer lies in refining the mathematics and checking the sums ${ }_{r}$ adding more factors and variables into the calculations in deciding where the overall balance of cost/benefit lies.

There are, I suggest, at least two possible ways in which this moral certainty and moral closure are supposed to arise. First, it might be held that as an empirical fact, the moral universe is complete - there are no moral black holes. Alternatively, it might be held that moral agents are complete - we have the rational capacity to generate and demonstrate the correct moral answer to any moral question from established moral principles and axioms. The first model is the Moral Marksman approach - the truth is out there, patiently awaiting the arrival of the seeker after truth; the second model is the moralist as mathematician, where appropriate axioms will generate all the necessary moral inferences. My thesis is that both models are wrong; in fact there are the moral equivalents to black holes, where there is no settled moral truth patiently waiting nor is there a rational principled method in us as moral agents which will yield a unique answer. Both approaches fail, most especially when the moral stakes are at their highest, or when an unambiguous decision is required. Somehow, "Do whatever it is that will maximise happiness" is hollow advice, but so is "Do your moral duty".

\section{MORAL FAILINGS - WHY MORAL THEORIES MUST FALL SHORT}

Morally sensitive people look to, and maybe even rely upon, a preferred ethical theory as providing a guide for the perplexed. But, I think that the gigantic steps made in biotechnology generally and in genetics in particular have identified a lacuna in ethical theory, whatever kind of theory it may be; further the lacuna is not restricted to advances in biotechnology alone, rather it is implicit in technological advances in all forms when they outstrip the commonplace.

We simply do not have the familiarity, the knowledge or experience in these areas to assimilate them under our existing theories of morality. Those theories were developed in simpler times, before in utero surgery and genetic modifications were dreamed of, let alone practised. But now these things are here, and we cannot revert to ignorance. Indeed, talk of genetics has become part of ordinary discourse, with people being very quick to attribute just about anything to "it's all in his genes". Biotechnological questions, especially those about genetic engineering are seen as raising moral issues and as being at least in part moral questions.

Sometimes a person may toss off an answer thinking that they have provided a moral response - for example, when asked "Should anyone take a genetic sample from someone else without that person's consent?" most have not seen the question as odd. Answers are 
forthcoming. The usual answer seems to be "no", with some explanation in terms either of privacy or autonomy or ownership of one's genes. This is surely surprising in relation to a subject matter which was unknown to all 50 years ago, and unknown to most ten years ago. When did we suddenly acquire beliefs about the moral status of one's genes? But, if one asks further, "When was the last time your hairdresser asked for your permission?" the stock reply may be to treat it as a trick question. And then the previously unqualified answer gets provisos or explanations attached and the picture becomes much more complex. The further elaborations are heterogenous, and what was initially supposed to be a moral answer may emerge as something else, be it a legal, political, social or cultural. It no longer has the kind of certainty and universality that a deontological or consequentialist moral theory espouses. There is a recognition of the need for an answer to these types of question, because the situation exists: someone needs to know for instance whether all the relevant parties have been consulted in a proposed drug trial involving genotyping, whether a person can "sell" their genetic information for profit, whether they can flush the unused fertilised preembryos down the drain, or whether they can implant them in a non-donor (as if a form of adoption at a very early developmental stage). The questions will not disappear, nor will traditional ethics provide answers.

Some of the complexity is the search for a non-legal interpretation of a legal concept, such as ownership (and too often the view is that one owns one's genes just like one owns one's jeans). Some of it is about social policy-forming, (Big Brother checking up and keeping records, prospective employers, or insurance companies having a questionnaire covering an applicant's genetic state: Are you now or have you ever been genetically identified as a haemophiliac/dyslexic/alcoholic/kleptomaniac?). Some of it is about commercial economic power, biomedical research and clinical trials conducted on behalf the multinational pharmaceutical companies where the parties are not on an even playing field. Rather, the pharmaceutical company has all the information, and the economic and political influence potentially to force gene-gleaning and the answer-givers do not want to see institutional invasion of one's body - they see it as a body-cavity search for drugs, where the agendas of the participants are at odds, with the company in it for profit, but the participant in it for social, often altruistic reasons. Finally others see it as a contractual question (here, more responses tend to be highly legalistic, about lack of consideration and disparity of the parties).

However, although I am focussing here on genetic sampling, the range of issues arising in biotechnology is far more expansive. One has only to consider the topics in assisted human reproduction, in vitro fertilisation and frozen embryos to realise that these are new subjects. Some people understand the science involved, but these topics are among the matters with which we have no pre-standing experiential familiarity. We do not know how to be Kantian or utilitarian about "left over" frozen embryos. What maxims are at issue, and how would one decide which, if any, one could will should be a universal law? Is an 
embryo an "end in itself" or something else? Similarly for the utilitarian, should the embryo figure in the equation as a potential sentient, given that it is not sentient in its present state and is not capable of becoming sentient unless further steps are taken? This latter factor certainly distinguishes the frozen embryo from the embryo in utero, which in the ordinary course of events will develop into foetus and ultimately will be a fully fledged member of the sentient species. ${ }^{11}$

But, if indeed there are moral gaps, that does not make life easy for those looking at the questions and needing answers. And whereas ethicists can remain undecided on the issues, practitioners, judges and political policy makers cannot. Moreover, because they are making decisions, they are informing our ethical theories. The results establish new data, new empirical items as information on the basis of which to expand or amend ethical theory. In that way, they are inventing ethics. After all is said and done, the subject matter of ethics is experiential, and in particular it is about human activity, how we live and what we do. But only by assuming that experiences have been had to the fullest extent can we even begin to imagine that there is nothing new in the future.

But there is a further second reason for maintaining the incompleteness of ethics, which some might think is just an empty logical reason. It is simply this: we can never be sure that there will not arise a question for which we have no answer. In the positive version: we cannot know that we have reached the end of all questions, and so that there are no unanswered questions. We cannot, as it were, get to the end of the list of questions, but unlike reciting the series of positive integers $(1,2,3,4, \ldots$.$) , we do not know how to generate$

11 The problems are canvassed in Davis v Davis (1992) 842 SW 2d 588 (Tenn Sup Ct), where, in determining the dispute between a divorcing couple over seven frozen pre-embryos, the Supreme Court held that the State Court of Appeals had miscast the issue as a persons or property issue,(Unreported Junior Lewis Davis v Mary Sue Davis, Tennessee Court of Appeals at Knoxville, 1990 WL 130807 ). Having decided that the pre-embryos did not fall within the meaning of persons within Tennessee and US law, the Court of Appeals held, roughly put: if they are not persons, then they must be property, so the issues are of chattel ownership and bailment by the Knoxville Fertility Clinic. The Court of Appeals went on to award joint-custody! On further appeal, the Supreme Court rejected the classification dichotomy, and stated that the frozen preembryos were in "an interim category because of their potential for human life. It follows that any interest Mary Sue Davis and Junior Davis have ... is not a true property interest. However they do have an interest in the nature of ownership". The Supreme Court then adopted an approach based on balancing the parties' interests, holding in these circumstances that the "father's" opposition to the use of the pre-embryos outweighed the "mother's" desire either to use them herself or to donate them to an infertile couple. But the court recognised that it was constrained by legal considerations and categories and was unable to adopt what might be called a "lawneutral" stance. So it was quick to point out that it was effectively setting a legal policy, "But the rule does not contemplate the creation of an automatic veto, and in affirming the judgment of the Court of Appeals, we would not wish to be interpreted as so holding." (per Daughtrey J., Ten Sup Ct) 
the questions series. We do not have what logicians call a "recursive function" to give us the next question in the ethical questions series, the " +1 " rule that tells us how to generate the next positive integer in the series. Some might maintain that the fact that we cannot know that we have reached the end of ethical investigation is a very good reason for claiming that as far as we are concerned, it will always be complete. ${ }^{12}$ But this is a mistake, in that it identifies "decided" with "decidable". It presupposes the effective closure of ethical theories and, by implication assimilates moral decision making to legal decision making. Whereas in legal decision making we can identify in advance the rubric for what would count as a legal decision in any given society, by reference to the legal system and legal institutions for that society, the same does not hold true for ethics, unless one adopts a relativist view of ethics as being just an anthropologist's generalisations about the behaviours of certain ethnic, social or geographically contained groups and abandons all claim to universality. Such relativism will leave ethics as descriptive, just when we need it to be prescriptive.

But what I am maintaining is that current moral theories necessarily leave gaps. The questions may very well be answerable, but not answered by application of moral theories as they stand. We learn from our experiences. Finding or deciding on an answer is to extend, amend or rescind the existing theory. I submit there is no satisfactory principle of closure, only an arbitrary one at any given time - arbitrary but not irrational. This is what we might call, creative ethics, and it is in this area that there is greatest interest, because the questions tend to be arising in the professional and applied fields. Moral theories are at most, best working hypotheses, given the nature of our knowledge and experience, about how we should act. It is no coincidence that there is a sudden growth in medical ethics and technology ethics, the experiential raw data is too new and too different to be subsumed under existing norms and yet does not fall prey to social relativism. One example in the literature of the kind of thing I mean is John Harris's question: "by what criteria might we decide on meeting a creature from outer space to have him for dinner in one sense rather than the other?"13 Whereas that is fiction, modern biotechnology is beginning to give us the real questions.

Ethics is a practice but a rational practice: it grows to meet our needs. At present our classical moral theories do not meet the needs - they need to grow to help one determine how to behave to and with others. It is not going to tell you whether it is acceptable to eat the

12 I would like to thank the anonymous referee of an earlier version of this paper for bringing this point to my attention.

13 J Harris The Value of Life: an Introduction to Medical Ethics (London, Routledge \& Kegan Paul, 1985) cited in R Gillon Philosophical Medical Ethics (Chichester, John Wiley \& Sons, 1985) 184. I think the question misses the mark somewhat in that one's deciding criteria might be self-interested prudential concern about toxicity, rather than about moral probity of eating Martians. 
Martians for dinner, (we had Danish for breakfast, and Martians for dinner). Our ethical beliefs both inform us as to conduct and also as to what is to count as an ethical object, but only by extension from the kinds of thing we already know, and accept. Then when we find ourselves in disbelief as to the moral status of something, we have found a hole in our moral theory. ${ }^{14}$ We have encountered a situation which does not neatly fit under any of our current recognised categories. Again, it might be replied, all I have shown, if anything, is that we do not know whether we have complete closure in our ethics, rather than that closure cannot be attained. But that is to overlook the obvious, we cannot know how much we don't know, and however much we might hope we'll get by, we are not prepared.

Many of us will tend to err on the side of caution, which might incline one against eating the things out of the spacecraft from Mars (maybe they are poisonous, maybe it is Martian detritus or excrement, maybe they are people, in a morally relevant way, but whichever, best not to be eaten). But erring on the side of caution is like Pascal's wager for the belief in God I've not lost anything if there is no God at the end of my earthly days, but I might really get heck if I don't believe and it turns out I was wrong. By parity, when the Martians disembark on your front lawn, you might decide it is inappropriate to eat them, not because they are definitely moral agents themselves, or even moral objects like your pet basset hound, but maybe because they might be. You just don't know enough to make an informed decision. If they turn out to be like the Mars Pathfinder vehicles, controlled robots, then you might

14 It must strike most people nowadays as utterly amazing that the American Civil War was precipitated in part by the Dred Scott case, a case where the US Supreme Court was divided on the issue whether Dred Scott, his wife and two daughters were even people - not the narrower term, citizen. Perhaps more amazingly, the State Circuit Court of St. Louis, Missouri, had granted Scott a declaration of his freedom (because he had been brought into Missouri from Illinios, a nonslave owning State, having been taken there by his owner, an Army surgeon, and had been sold in Missouri). The case fell on the issue that Scott could not petition any court for anything, because he was not a person, but was property; hence the Missouri Circuit Court declaration was a nullity. The for the decision reads, in part:

4. A free Negro of the African race, whose ancestors were brought to this country and sold as slaves, is not a "citizen" within the meaning of the Constitution of the United States.

5. When the Constitution was adopted, they were not regarded in any of the States as members of the community which constituted the State, and were not numbered among its "people or citizens" ... .

6. The only two clauses in the Constitution which point to this race, treat them as persons. who it was morally lawful to deal in as articles of property ... .

...4. The Constitution of the United States recognises slaves as property, and pledges the Federal Government to protect it. [emphasis added]

Dred Scott v. Sandford (1856) US Reports 60, How v19, 393 - 633 (US Supreme Court, December Term). 
assimilate them to your radio, which you would probably not be inclined to eat, or else to something more like object trouve chocolate bars, which you might eat.

\section{BIOMEDICAL TECHNOLOGICAL ADVANCES - GENE WARFARE}

"Gene transfer" has the ring of something highly unusual and technologically manipulated, but that is not invariably so. One form of gene transfer is called vertical gene transfer: that is the transfer of genetic material from parent to offspring through conception, the norm in mammalian sexual reproduction. Another form of gene transfer is called horizontal gene transfer, when the genes from one zoon enter a different life-form. It too is commonplace, in some forms: we all get viral flu, and become the unknown, unconsenting and unwilling host to germs. The virus will have entered the body and will be replicating and mutating while the body's immune system strives to thwart the invader, and the inner struggle manifests itself in flu symptoms. That is not spectacular. What is spectacular, is that we understand the mechanisms. But by coming to understand the mechanisms we have gained dangerous knowledge; we - or at least, some scientists - know how to effect changes in genetic structure and how to implant those changes into existing creatures in such a way that the characteristics will be passed on to the next generation (vertical gene transfer), and to approximately 16 generations before some further mutation might appear. When the changes to genetic structure affect (or are supposed to affect) only non-inheritable characteristics, they are said to constitute somatic gene alteration - and where the intended single generation change is intended to benefit only the recipient, it is called somatic gene therapy. It is supposed to relieve the sufferer of a genetic disorder, without changing the germ line - inheritable traits - genes. Where the change is intended or thought to pass on to subsequent generations, it is called germ line alteration, or germ line therapy.

So in contrast with ordinary gene transfer we must be ready to ask questions when the genetic structure is deliberately altered by us for our own purposes, whether it be somatic gene therapy or germline gene therapy, precisely because those matters are in our control. For the moment they are; we can choose not to pursue genetic modification, but technology, policy and legislation are all moving rapidly to permit genetic modification. Genetic engineering is proposed for reproducing woolly mammoths by taking the fertilised ova from elephants, and replacing the existing elephantine genetic string in the nucleus with that taken from a frozen woolly mammoth. It is intended to be germline, in that the reconstructed woolly mammoth should be able to reproduce, and reproduce woolly mammoths not elephants. Similarly, xenotransplantation and genetic modification in foodstuffs are now feasible. Xenotransplantation involves genetically altering organs in other species, typically pigs, to make the organ more suitable for transplant into a human, (and thus reduce the likelihood of organ rejection by the recipient). The thinking is that a bank of tailor-made modified animals could be bred with the germline alteration to create a plentiful supply of organs for humans. This is an extremely moot topic, not only because it involves the 
deliberate use of other living creatures for human ends, but also because it involves genetically modifying them first to make them better suited to human interests. Those who baulk at using animals on the grounds of sentience, (utilitarians) might find themselves accepting such use where the genetically modified donor bank is modified to the extent that it is not sentient, say where the individuals are being bred headless ${ }^{15}$ and so have no centre of consciousness. Those who baulk at using animals on the grounds of breach of the autonomy of another species member would object to that headless modification. ${ }^{16}$ Genetic engineering in foodstuffs is gaining momentum, involving in some cases horizontal gene transfer from two or more non-sentient vegetables to increase disease resistance, or yield, and sometimes involving genetic transfer across the sentience/non-sentience line, such as salmon and strawberry mixing to create a cold-resistant strawberry. Self genetic replication, the Jenny Gee example, is just another case of the possible application of the new knowledge of genetics.

But, we have no past guidelines, no experience of what happens when one living thing is deliberately changed in its very essence, unless you take seriously stories about turning water into wine (how come it was never the other way round? would we have heard of it if it had been? ${ }^{17}$ ) and we do not know what inferences to draw. We just lack the kind of broad experience which seems to underpin an ethical judgment. We are like children in this regard; and just as we do not expect toddlers to go around making complex moral judgements, but rather we foster and watch develop moral awareness and application, we too need more experience. Currently matters are too novel and too different to fit into any of usual categories. We are used to farmers selecting their best stock for breeding, but most of us would have dismissed as a bit unhinged the farmer who said he had selected his best tomato and his best chicken for interbreeding, even if he said that it would take a lot of trial and error, but it would give a more juicy chicken with a hint of a tomato sauce taste.

The difficulties are also compounded by our own arrogance, our willingness to act as if we had correctly characterised whatever it may be as non-germline, or as non-horizontal modification. For example, thalidomide was not thought of as a germ-line affecting drug, but now evidence suggests that the adverse effects are carried vertically by germ-line, meaning

15 Apparently this has recently been done with tadpoles, but it is a long phylogenic step from amphibians to mammals and to the application of the technique to mammals, and advanced mammals at that.

16 There is a very instructive argument to be made here in evolutionary biology which would see the individual as subordinate to the species, so that the autonomy argument is raised from the individual autonomy level to the species autonomy level. The argument would take me too far afield for this paper, but it can be followed through the writings of evolutionary biologists.

17 Thinking in legal mode, I can imagine this generating breach of contract actions, or at least actions for conversion. 
that there is now a second generation of thalidomide affected people. It seems that germline modification occurred, and presumably will be passed on as a heritable trait. ${ }^{18}$ By parity, Scandinavian field tests on vegetables through genetic modification, designed to produce disease resistance has apparently resulted in resistance being genetically transferred into weeds. Again, an unexpected and unprepared for result has arisen. With the best will in the world, little credence can be put in the information fact sheets about genetic modifications and the reliability of predictions as to effects.

\section{LEGAL DECISIONS, POLICY AND MORALS}

If the genetic modification is undertaken, then it cannot be pulled back, it is out of our control. Yet when we consider whether these processes are ethical, we have not had the experience sufficient to inform our ethical stance. Scientifically we know these things can be done and indeed are being done. Applications for New Zealand field tests on genetically modified brassica plants (cabbage family plants) and pinus radiata tree stock have been publicly notified in the newspaper in late 1997 in accordance with the requirements of the New Zealand Hazardous Substances and New Organisms Act 1996, the Biosecurity Act 1993 and the Resource Management Act 1991. These notices appear as nondescript entries, with no specific mention of the legislation's title, in the Public Notices Section of the Saturday paper, surrounded by notices about bars applying to renew their liquor licences and companies going into liquidation. There is a potential risk of genetic material being transferred (horizontal gene transfer) to other species, but without the pilot studies, the statistical modelling is frankly guesstimating, with an expressed margin of error of up to $100 \%$. Yet approval for such trials to go ahead may be granted if, in the words of the Hazardous Substances and New Organisms Act," the organism meets the minimum standards set out in section 36 and ... the positive effects of the organism outweigh the adverse effects."19

18 Contrary to popular belief, thalidomide is still in use. It a treatment of last resort for blisters in the mouth, having a demonstrated ameliorative affect in otherwise intractable cases. Needless to say, the information sheets provided to potential recipients are plastered with cautions in every font and letter size imaginable.

19 The minimum standards to be met are set out in s 36 :

The Authority shall decline the application, if the new organism is likely to:

(a) Cause any significant displacement of any native species within its natural habitat; or

(b) Cause any significant deterioration of natural habitats; or

(c) Cause any significant adverse effects on human health and safety; or

(d) Cause any significant adverse effect to New Zealand's inherent genetic diversity; or

(e) Cause disease, be parasitic, or become a vector for human, animal, or plant disease, unless the purpose of that importation or release is to import or release an organism to cause disease, be a parasite, or a vector for disease.

all of which, in relation to genetically modified material is to be fast-track assessed under 
The Hazardous Substances and New Organisms Act 1996 is legislation intended to cover all types of dangerous things, other than humans or organisms derived from humans (an odd exception, surely). So it covers, for instance: fireworks, poisons and non-human, genetically modified materials as well as organisms new to New Zealand at the time of proclamation. It regulates by establishing the ERMA (Environmental Risk Management Authority) which is empowered to licence testing, deployment and use of hazardous substances and new organisms. When the matter of human genetic manipulation was considered, the Final Report to the Health Research Council Ethics Committee stated: ${ }^{20}$

Most human genes have homologues in other species. Use of the non-human homologue may suffice in some cases. The conclusions reached are that:...

- $\quad$ existing regulatory authority (IAG, ACNGT) ${ }^{21}$ is sufficient for approval of gene transfer into non-human species, and

- IAG or ACNGT should require applicants to justify the use of a human DNA sequence as opposed to its non-human homologue.

The Council further commented that "Neither of the two advisory committees has any legislative authority. In part, to address this, the Government intends to establish an independent agency, the Environmental Risk Management Authority (ERMA)" ${ }^{22}$

The result is that since the new legislation expressly excludes human genetic technologies such matters are left to local accredited Ethics Committees (established under the Health Research Council Act 1990) and other general legislation on health, healthcare and medicines. But Ethics Committees have no mandate specifically to prohibit or prevent procedures, only to approve or decline approval. Lack of accredited Ethics Committee approval results in participants not being eligible for coverage by the Accident Compensation Corporation for any injuries, loss or damage which would otherwise have been eligible. However, it is not the role of ethics committees to legislate; that is the function of Parliament and of the courts in deciding cases.

s 42 which provides:

(1) Where the Authority receives an application under section 40 of this Act to develop a genetically modified organism in containment, the Authority may make a rapid assessment of the adverse effects of developing that organism.

20 The Health Research Council of New Zealand, The Clinical and Research Use of Human Genetic Material: Guidelines for Ethical, Cultural and Scientific Assessment (December, 1995)

21 Genetically Modified Organisms Interim Assessment Group and the Advisory Committee on Novel Genetic Techniques respectively

22 Above $n 20$. 
Ethically should strawberries be genetically modified, with the result that they can be grown over extended growing seasons, or in colder climates? Should we hedge our bets in the face of a possible unknown spread of promiscuous deviant brassica or unanticipated complications in modified strawberries? I think so. But if we do so, it may be prudent, but not much more. Then, again, it will be a legal decision which is made: the application will be granted or refused. The arbiter will be considering the nature of the application, the experience of the applicant in such matters, the known and perceived risks to the environment if the application were to be granted and any other matters the commissioner or ultimately the Court - thinks fit in the circumstances. A legal decision will be made, and one which creates a precedent, a precedent which subsequent courts may ignore at their peril.

Similarly, if Genepharmicals Ltd develops a genetic modification, for instance intended for treating osteoporosis, (it is now generally believed that there is an osteoporosis gene), legally they might be entitled to patent it as a process, but is it ethical? If it turns out that that modification is based on a single individual's particular genetic difference from her osteo-afflicted sister, should Genepharmical be able to claim ownership in the unaffected sister's gene difference? Can they acquire her genetic information, either by buying it from her, or by her simply giving them it, wholly altruistically in research to find out why people like her don't have, but people like her sister do have osteoporosis? Drug companies are all racing to the patent office as quickly as they can, court battles are already in full swing between the companies as to which has ownership in a particular piece of genetic information. You have only to browse the Intellectual Property Law Reports to see how many legal decisions are being made, piecemeal, in the absence of clear cut ethics, and indeed in the absence of policy.

Policy makers, government agencies and professional associations are racing to come up with policies and guidelines. But both the legal decisions are being reached and the policy is being formulated in a rush and under pressure. These are being made because they have to be made in response to this particular issue, this particular application here and now. Although the legal decisions are being rendered, courts do so reluctantly. Davis v Davis ${ }^{23}$ illustrates well the quandary when the court must render judgment where "we have no statutory authority or common law precedents to guide us".

In their recent Health Care Law: Texts and Materials the authors state: ${ }^{24}$

23 Above $n 13$

24 J McHale, M Fox, J Murphy, Health Care Law: Text and Materials (London, Sweet \& Maxwell, 1997) 71. The second justification - that of insufficiently developed law - is curiously illustrated by equitable remedies for breach of confidence. It seems almost too manageable to be challenging. 
We have three main reasons for considering ethical approaches separately from and prior to examining the law in depth. First, many of the legal principles we will consider purport to be based on ethical foundations - for example, it is claimed that our law on consent to treatment is based on respect for autonomy. Secondly, on many of the topics we will consider, law is insufficiently developed to provide guidance for health care professionals - this is true, for instance of the equitable remedy of breach of confidentiality. Thirdly, there may be ethical reasons for not attempting to extend law into certain areas - for example, some would argue that this is the case with attempts to regulate the behaviour of pregnant women...

The second and third reasons combined seem to imply that in legally unchartered areas there will nonetheless be ethical charts. This, I maintain, is misplaced optimism when it comes to new technologies which expand beyond our established cognitive horizons. Although I have argued only the case for medical technologies, it is only one example of the problem.

\section{MORAL HYPOTHESIS AND SKILL}

Here is the disparity between law, policy and ethics. Judges and policy makers need to reach some specific single determination or prescription. That is what they are required to do. Theirs are specific roles within society. Judges adjudicate specific claims of specific individuals, and all this against a background that will have involved out-of-court negotiations. In other words, there is an artificial closure on issues decided by judges. The closure is twofold: society establishes the role, sets the mandate and the functions to be performed; the litigants set the issue to be decided. Policy makers operate under general directives with political and economic underpinning; they must provide a policy, in keeping with the overall structure within which and in terms of which they are policy makers. By contrast, ethics is not a social institution, with a specific function and job-description attached. Ethicists can ponder. Importantly, they can entertain counterfactuals as well as hypotheticals, and consider what other facts and factors might be relevant: they can act as the gadfly in the side of the state; they can come to a tentative thesis, without being committed to it in practice; they can come to no conclusion, other than to show what is wrong with other approaches; tentative hypotheses can be reviewed, reconsidered, rehashed and the question and the subject matter remain. Ethicists can adopt different general moral theories, the consequentialist, the deontologists and the others, and each approach can generate a different and even possibly several different possible answers without having to dismantle the theory for its failure to come up with the quick solution. Solutions are made to particular problems, ethics informs the manner of approach to types of problem. Ethics is a training, the acquisition of the skill of living the good life, where one learns by asking the question, and not by finding the answer. I am inclined to think that Plato/Socrates got it right: living the good life is a craft, but unlike Plato I think it is a craft where you can't have too many practitioners. 
Pluralism accommodates a variety of ethical attitudes, but the law and policy cannot. They serve very different social functions. They are there to decide legal issues between persons, or to declare a person's rights; they are there to provide a social guideline, albeit a probative guideline which may be revised over the years. Ethics, in contrast, is supposed to help us with searching for answers to the question, and perhaps even more importantly with identifying questions concerning not whether thus-and-such is legal, not whether it is institutionally accepted, but whether it is right. But with new situations, such decisions cannot be made ex nihilo. So while we must put a lot of time and thought into developing our ethical outlook to deal with the utter novelty in new technology, we must be sure too that we are working to ensure that those other institutions, the judges, the policy makers and indeed the technologists themselves are mindful of the limited scope of their roles, and that the individuals who fill those roles heed the need to strive for moral goodness, not just novelty or decisions. 